\title{
Agro Software Development in South - East Region
}

\author{
Daniela Lavinia Balasan ${ }^{\star}$, Florin Marian Buhociu ${ }^{\star \star}$
}

\begin{tabular}{l}
\hline \multicolumn{1}{c}{ A R T I C L E I N F O } \\
\hline Article history: \\
Accepted October 2020 \\
Available online December 2020 \\
\hline JEL Classification \\
Q10, Q20, Q56 \\
Keywords: \\
Development, Rural potential, \\
Indicators, Project, Capacity.
\end{tabular}

\begin{abstract}
A B S T R A C T
In this paper I set out to discover emerging technological tools in the field of agriculture in order to improve the quality of this environment. These instruments will lead to the creation of a plan capable of making it possible to increase the competitiveness of the South-East region. The field of intelligence is today the standard of industrial policy in Europe. It requires that financial resources and other support instruments focus on priority areas that can lead to the successful development of the region. In order to collect information to identify as accurately as possible all resources that can exploit the potential for innovation, we have created a website based on the advice of small entrepreneurs in the rural area of Sid -Est.
\end{abstract}

(C) 2020 EAI. All rights reserved.

\section{Introduction}

In this paper, I set out to analyse the main tools useful for developing a management model of a study on sustainable agriculture in the South-East Region by assessing and measuring the sustainability of agricultural holdings in this region. The economic basis for the development of the village is determined by the agricultural holding which is lower due to the low capacity to invest.

The region under review enjoys the fact that it includes almost all forms of relief, and the opening to the Black Sea offers the opportunity to develop the maritime and river-maritime domain, and is also an element of attracting foreign investors. The region is the second largest in Romania and comprises six counties, namely Brăirela, Buzău, Constanta, Galați, Constanța County being the most economically developed. Tulcea and Vrancea. In the figure below we see the geographical positioning of the South-East Region in Romania.

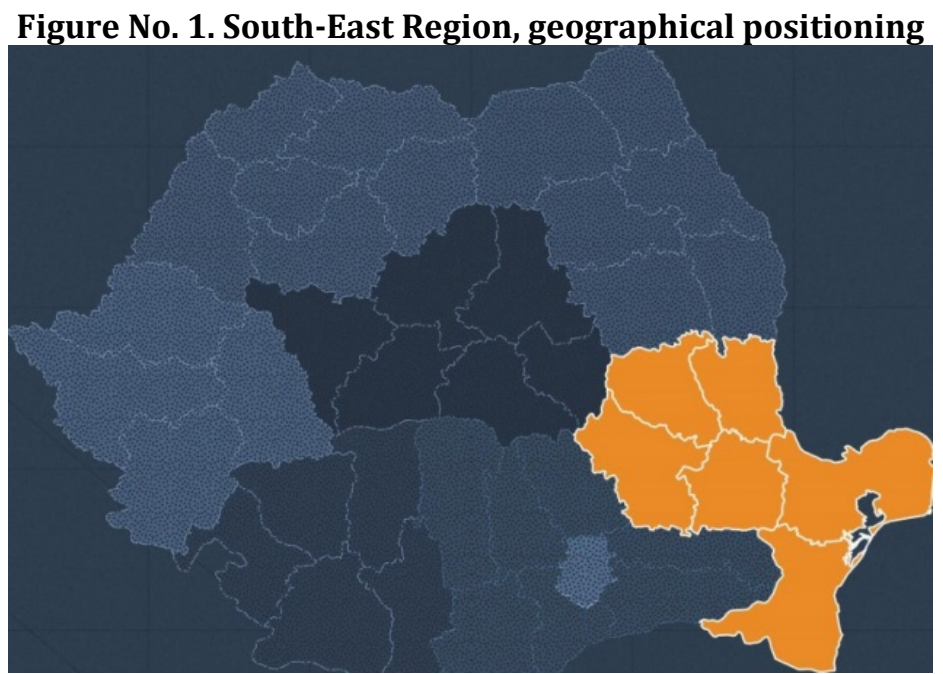

Source: Image taken from the Workshop of Entrepreneurial Discovery in the field of Agri-Food Region South - East

The paper refers to the anassembly of elements that solve social, climate, environmental, demographic, and especially economic challenges. In order to achieve an efficient characterization and to classify the region in relation to the other development regions of Romania, it is important to carry out an analysis on economic performance through indicators such as gross domestic product, number of inhabitants, gross value added, total active employment contracts.

The work is divided into two parts. In the first part I chose to talk about the importance of smart specialisation in developing competitiveness within the region, and in the second part I detailed the tools that 
help improve access to vocational training in the region. Smart development lays its foundations on entrepreneurship and more specifically on the region's imported development areas and those with development potential for the future.

The 2South-East region is located in the South-East region of Romania and borders the North-East Region, the Central Region, the South Region - Muntenia and the Bucharest-Ilfov Region. An essential element of geographical location is that it is located at the eastern border point of the European Union and on the east lays the Black Sea coast. This region is the second largest in the region of our country.

The definition of rural devoting is inscribed in a broader concept, that of the rural economy, as a branch of economic science intersecting with rural space and agriculture, with the environment economy and the development economy. At the base of the rural economy is the economy of the agricultural holding with its market-related valences, agroalementation Industries which makes the analyses of the rural economy associated with rural policy, agri-food consumption and agricultural policy.

\section{The role of smart specialisation in the development of regional competitiveness}

"The nation that destroys its soil destroys itself." (Soil Erosion, Franklin D. Roosevelt)

Smart specialisation involves a strategic approach to innovation in research at international, national and regional level.

The strategic approach helps to support the following instruments, namely:

$>$ Smart development through effective investment in education, research and innovation;

$>$ Sustainable development based on a cost-effective economy;

$>$ Developing places of one and reducing poverty levels.

Among the great challenges of contemporary agriculture is the population which is growing quite rapidly, but which is increasingly distancing itself from agricultural production, leading to soil degradation. The environmental consequences are quite high due to increased cultivation. These consequences could be eliminated with the help of much more diversified agricultural practices andquality, such as water andsoilmanagement, crop diversification, a system resistant to sudden climate change.

Intelligent development of agriculture requires advice and stabilisation of farmers' skills. The agricultural sector of the South-East Region contains strong elements that lead to the development of entrepreneurship in this area.

This is based on important resources for the agri-food sector, but more than $60 \%$ of agricultural production is exported, for example cereals and oil plants. If Galati and Constanta counties rely on the service sector, the other four counties of the region focus heavily on the agri-food sector. Here we meet field crops, fish farming, vines, and horticulture.

Figure No. 2. Gross Domestic Product in the South-East Region (million lei)

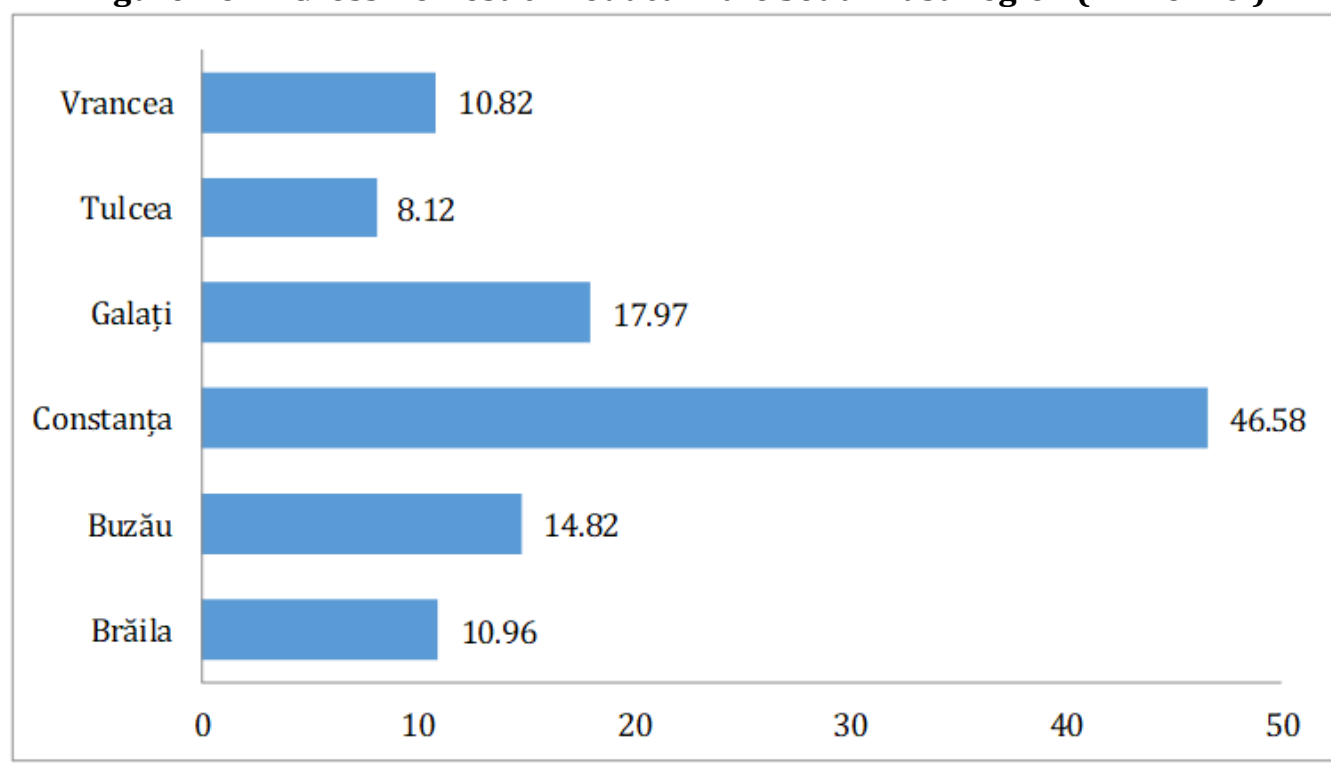

Source: Own processed data from the National Strategy and Forecast Commission published in December 2019

More than half of the farms in the South-East Region have a small area, about two hectares. The South-East region is below the European average in terms of agricultural technology facilities.

In the South-East Region the activity that dominates is agriculture, with a share of almost $33.2 \%$ of the total number of inhabitants, but still, the workforce is poorly developed. Climate conditions favour the cultivation of cereals, maize in particular in the northern area and wheat in the central area.

Strengths in areas of smart development are: 
$>$ Decrease in environmental pollution;

$>$ Increasing the level of quantity and quality of foodstuffs;

$>$ Supporting research and development in order to harness the degree of alternative energy;

$>$ Promotion of the tourism sector;

$>$ Improving access to vocational training.

In achieving the intelligent development process of the region analysed, several aspects must be taken into account, namely:

$>$ Increase the level of motivation of the labour force in the region;

$>$ Involvement of the academic sector in the conduct of research and innovation activities, as well as the application of proposed solutions;

$>$ Achieving sustainable partnerships;

The South-East region ranks first in Romania by vine area. Trade in fish is a traditional activity in this Region. In the following figure we see the share of the working population in the economic sectors.

\section{Figure No. 2. Participation of the civil active population in the main economic activities}

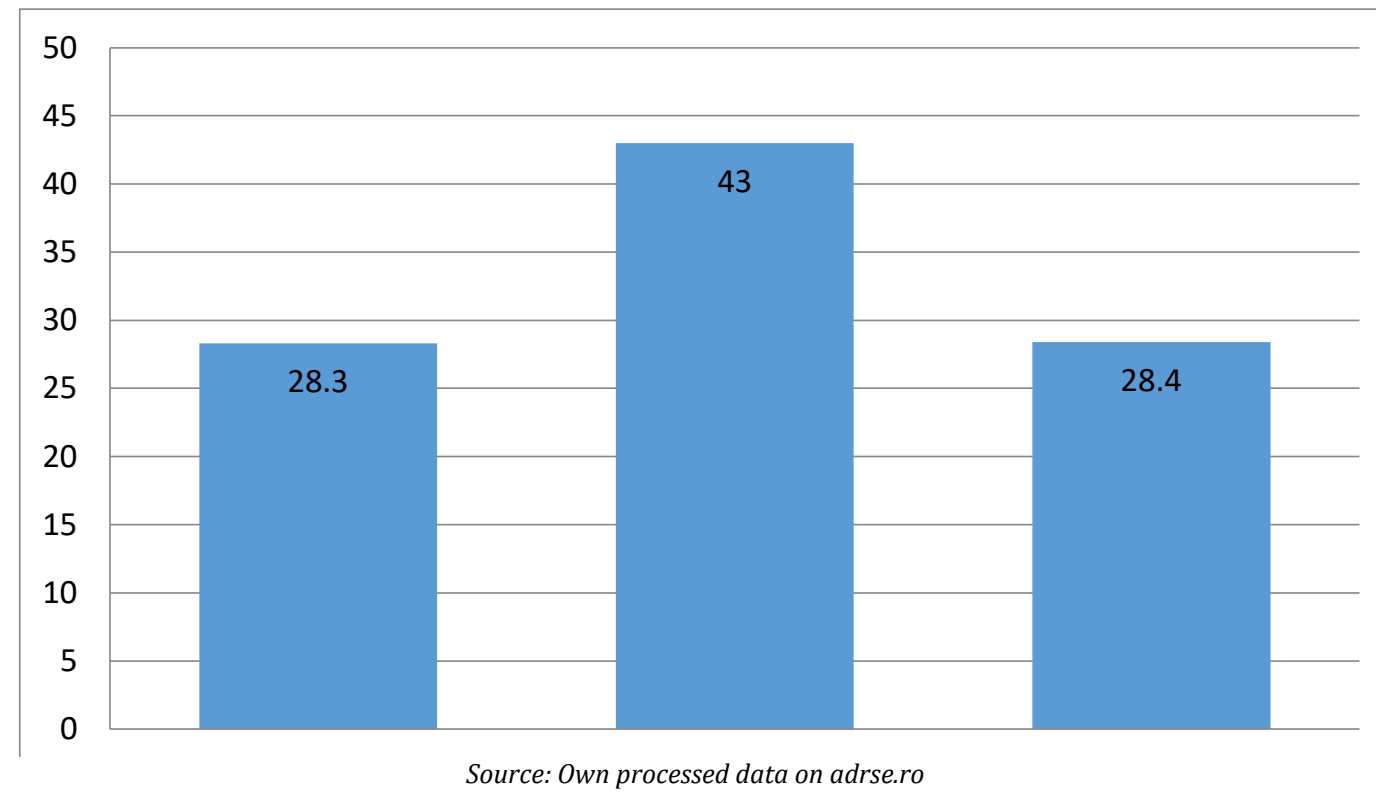

The civilian active population of the South-East Region has been decreasing in recent years due to significant emigration or unfavourable demographic trends. In recent years, fewer and fewer are interested in agriculture, and the population is interested in the information and communications sector, restaurants, hotels, administration.

In the counties of the region there is a balance between the number of men and the number of women working. Only in Constanta and Galati counties the differences are slightly more pronounced, the number of men with employment contracts being higher.

\section{Improving access to vocational training}

In order to analyse the development potential of Region 2South-East, we took into account the following elements:

$>$ Economy and labour force in Region 2South-East;

$>$ Entrepreneurship and investments in this region;

$>$ The advantages of the region, innovation and technological transfer of this development region;

$>$ Level of specialisation and improvement.

The recent decreases in the population require vocational training by:

$>$ Concentration of training in schools identified as viable in terms of local and regional potential for socio-economic development;

$>$ Elimination of unjustified parallelism in initial vocational training programmes for nearby schools;

$>$ The variety of initial vocational training programmes for schools in order to meet the needs;

$>$ Effective collaboration to make the best use of resources and cover education needs.

In the figure below we can see the average number of employees in the counties of the region registered in the last two years. 
Figure No. 3. Average number of employees by counties (thousands)

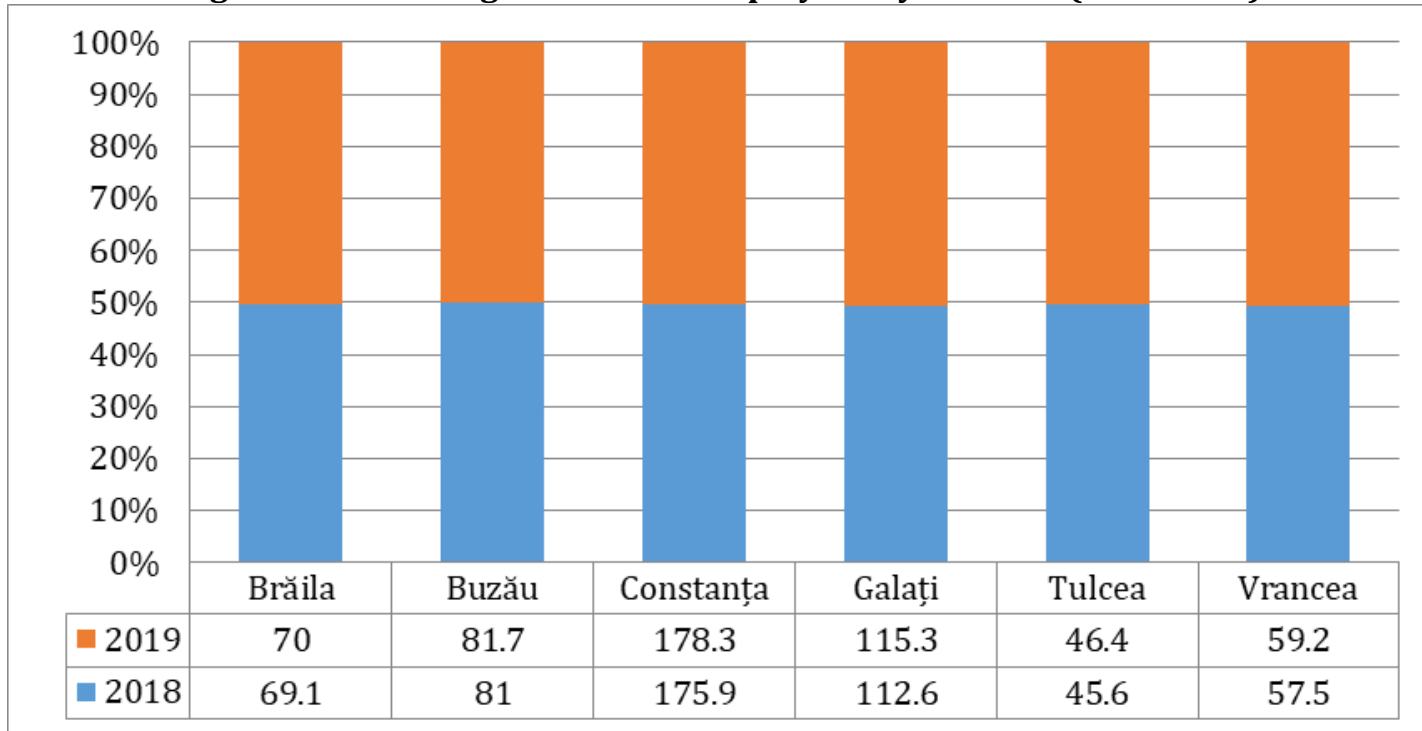

Source: Own processed data from the National Strategy and Progniscommission Commission published in December 2019

Constanta is the most developed county of the Region, followed by Galați, and in the last places is Vrancea and Tulcea.

Promoting competitiveness in order to develop high-performing business environments with competent and qualified human resources can represent the vision of the region. The South-East region cannot enjoy a large number of specialists in different specialized sectors, being in last place in this respect. In the figure below we see the distribution of the population of the South-East Region by age groups and residence environments.

Figure No. 4. Population by age and residence environments, South-East Region, 2018

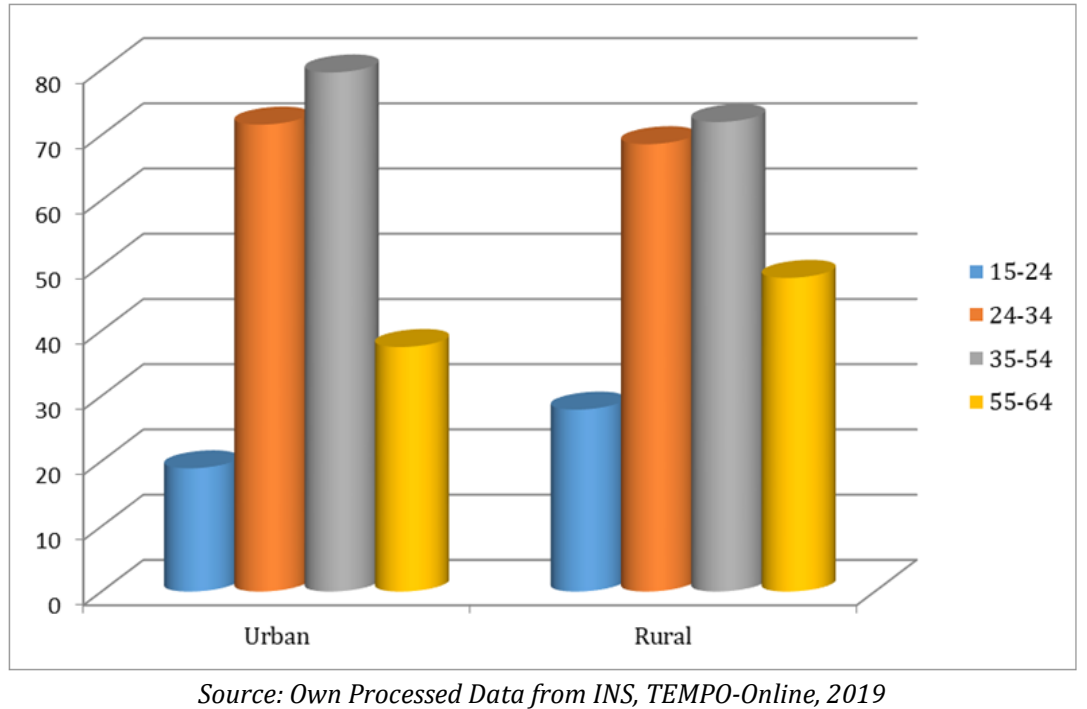

Today, development requires a transition from a cost-based economy to one that focuses on innovation. This requires companies to have the capacity to adapt to state-of-the-art technology and meet new market demands.

Innovation can be defined as the main tool for the growth of the economy. Thus, any change in the new, any adaptation to the new requirements, can be part of the development and innovation process. In the studied region there are only two technological information centres, namely, one in Constanta in the agrifood sector and the second is located in Tulcea County and is based on the field of environment and tourism.

\section{Conclusions}

Following this work, we have come to the main interpretation or elements necessary to carry out a model study aimed directly at the sustainable and sustainable development of agriculture in the South-East 
Region by assessing and measuring the sustainability of agricultural holdings in this area. Regarding the data analysed, the South-East Region does not record a very rapid development process.

In recent years, the South-East Region has seen a worrying reduction in the number of inhabitants, especially with regard to the labour market. It records the lowest nominal net earnings per month of all development regions.

The South-East region cannot enjoy the existence of clearly outlined policies that encourage entrepreneurs and encourage the research and innovation sector. Here are research centres and higher education institutions that could become pillars of boosting intelligent research and development in the region.

We have ticked off a number of issues facing the region, namely:

$>$ The need for skilled labour;

$>$ Taxes and taxes far too high for living conditions here;

$>$ It's a poorly developed entrepreneurial drive;

$>$ There are no services to support business development;

$>$ Weak development of the indrastructure and lack of modernization;

$>$ The existence of a very difficult and alabbic lending system.

In carrying out this work, we have come to the conclusion of the need for a management program for the development of human resources.

In order to reduce school drop-out and strengthen the pillars of schools within the region, it is recommended to be involved in adult training, community-based acts, studio contracts with entrances or institutions, consultancy, and last but not least, research and study.

\section{References}

1. Balasan L. D. "Rural Development in a cross-border context. Case Study: Romania - R. Moldova "Under the guidance of Prof. Dr. Ec. Habil. Daniel Bailey

2. Bleahu A., Rural development in the European Union, January, 2005.

3. Buhociu F.M., Teritoarial resources to support sustainable rural development in the European context, Europlus Publishing house, Galati, 2016

4. Clarles Ricq, Cross-border cooperation Manual for local and regional collective use in Europe, THIRD Edition, Bucharest, 2000

5. Constantin DL., Regional economics theories, models, policies, ASE Publishing house Bucharest, 2010

6. Dona I., Rural economy, Economic publishing house, Bucharest, 2007

7. Bold, E. Buciuman, N. Drăghici, Rural Area - Definition, Organization, Development, Timișoara, Mirton Publishing House 2003

8. Lupașc I., Lupashc A., Andone I., Using Intelligent Technologies For Improving Decision Processes, Iasi, 2010

9. Stanciu S., 2015, Security, Safety and Countinuity on Agri food Chain, Lambert Academic Publishing, Saarbrucken, Germany

10. Vasile, A.J., Ion, R.A., Turek rahoveanu, A. (coord.), Green Economic Structures in Modern Business and Society, IGI Global Publishing, 2016

11. Violette Rey, Coordinator, Romanian Atlas, Ed. RAO, Bucharest, 2006

12. ***Sociology dictionary, 1994, Coordinator Zamfir Vlăsceanu

13. ***Law No. 315 of 28 June 2014 updated on regional development in Romania, Chapter 1, article 3.

14. ***Manual of Cooperación Transfronteriza, European Association of Border Regions (AEBR), Berlim, 2014

15. ***Strategy for cross-border cooperation IEPV 2007-2013

16. ***National strategy for Regional Development of the Republic of Moldova 2013-2015, October, 2015

17. ***Study on labour analysis at the level of Romania's development regions for the year 2015

18. ***Joint Operational Programme Romania-Ukraine-Republca Moldova 2007-2013

19. ***http://zbw.eu/econisarchiv/xmlui/bitstream/handle/11159/127/St\%202_Cooperarea\%20transfrontaliera_final_0.pdf?sequence=1 \&isAllowed $=y$

20. ***https://utm.md/edu/legal/strategia_rm.pdf

21. ***http://www.transuei.ugal.ro/program.htm

22. ***http://www.adrse.ro/Documente/Planificare/PDR/2014/PDR.Sud_Est_2014.pdf

23. ***https://www.catchy.ro/regiunea-sud-est-din-romania-este-a-doua-cea-mai-saraca-din-ue/153246

24. ***http://infraed.ro/wp-content/uploads/2018/10/PRAI-SE-.pdf

25. ***https://www.piarom.ro/wp-content/uploads/2016/11/Studiu_forta_de_munca-2016.10.03-TIPAR.pdf?x44818 